\title{
Failure of getting intracranial translucency image in posterior fossa in the examination of singleton pregnancies at 11-13 weeks of gestation: reasons and outcomes
}

\author{
Derya Sivri Aydın' (D), Murat Yayla² (iD \\ ${ }^{1}$ Gynecology and Obstetrics Clinic, Haseki Training and Research Hospital, Health Sciences University, Istanbul, Turkey \\ ${ }^{2}$ Perinatology Clinic, International Hospital, Istanbul, Turkey
}

\begin{abstract}
Objective: To investigate the reasons and outcomes of being unable to see intracranial translucency (IT), and to determine the sensitivity, specificity, positive and negative predictive values and our diagnostic accuracy rate for the poor outcomes that may follow IT negativity.

Methods: This study was designed as the retrospective assessment of the data of 2670 singleton pregnancies. The evaluation of cerebral structures and posterior fossa was conducted on classical nuchal translucency evaluation plane and the cases, IT of whose could not be seen or measured, were included in the study. The distribution of chromosomal anomalies, malformations and fetal losses which may affect gestational prognosis as well as maternal characteristics of these cases was evaluated and they were compared with the group considered normal.

Results: The rate of the cases whose IT could not be measured in posterior fossa was $4.05 \%$. Compared to the group whose IT could be measured, poor prognosis of gestation, fetal loss or termination of pregnancy, chromosomopathy markers of early period and the presence of chromosomal anomaly, and the rate of central nervous system and other system malformations were higher in a statistically significant manner in the group whose IT could not be measured. Of the IT non-measurability, the sensitivity was $26.9 \%$, the specificity was $95.9 \%$, the positive predictive value was $21.9 \%$, the negative predictive value was $96.9 \%$, the accuracy rate was $93 \%$ and the odds ratio was 8.7 to predict the poor gestational prognosis mentioned above.

Conclusion: The findings of our study make us think that intracranial translucency can be used as a parameter helping classical methods for the early diagnosis of the malformations of central nervous system and other systems, and some chromosomal anomalies, and that it can be useful to use it in routine perinatal assessment.
\end{abstract}

Keywords: Intracranial translucency, ultrasonography at 11-13 weeks of gestation, central nervous system defect, chromosomal anomaly.
Özet: Tekil gebeliklerin 11-13 hafta incelemesinde posterior fossada intrakraniyal saydamlık görüntüsünün elde edilememesi: Nedenler ve sonuçlar

Amaç: İntrakraniyal saydamlık (IT) görülememesinin neden ve sonuçlarını araştırmak, IT negatifliğini takip edebilen olumsuzluklardaki duyarlılı̆̆ı, özgünlüğü, pozitif ve negatif belirleyicilikleri ve tanısal doğruluk oranımızı belirlemek.

Yöntem: Bu çalışma 2670 tekil gebeliğin verilerinin retrospektif değerlendirilmesi olarak tasarlandi. Serebral yapılar ve posterior fossa incelemesi klasik ense kalınlığı inceleme planında gerçekleştirildi ve IT’nin görülemediği veya ölçülemediği olgular çalışma grubunu oluşturdu. Bu olgulardaki maternal özelliklerin yanı sıra gebelik prognozuna etki edebilecek kromozom anomalileri, malformasyonlar ve fetüs kayıplarının dağılımı incelenerek normal olarak kabul edilen grup ile karşılaştırıldı.

Bulgular: Posterior fossada IT ölçülemeyen olgu oranı \%4.05 idi. IT ölçülebilmiş grup ile karşılaştırıldığında IT ölçülememiş olan grupta kötü gebelik prognozu, fetüs kaybı veya gebelik sonlandırma işlemi, erken döneme ait kromozomopati belirteçleri ile kromozom anomali varlığı, merkezi sinir sistemi ve diğer sistem malformasyonlarının oranı istatistiksel olarak anlamlı şekilde daha yüksek saptandı. IT görülememesinin yukarıda sayılan kötü gebelik prognozunu tahmin etmedeki duyarlılığ1 \%26.9, özgünlüğü \%95.9, pozitif belirleyiciliği \%21.9, negatif belirleyiciliği \%96.9, doğruluk oranı \%93, olasılık oranı 8.7 olarak saptandı.

Sonuç: Calışmamızda elde ettiğimiz bulgular, intrakraniyal saydamlığın merkezi sinir sistemi ve diğer sistem malformasyonları ile bazı kromozom anomalilerinin erken tanısında klasik yöntemlere yardımcı bir parametre olarak yer alabileceğini ve rutin perinatal incelemenin içinde kullanılmasının faydalı olabileceğini düşündürmektedir.

Anahtar sözcükler: İntrakraniyal saydamlık, 11-13 hafta ultrasonografi, merkezi sinir sistemi defekti, kromozom anomalisi.

Correspondence: Derya Sivri Aydın, MD. Gynecology and Obstetrics Clinic, Haseki Training and Research Hospital, Health Sciences University, Istanbul, Turkey. e-mail: deryasivri@hotmail.com / Received: March 11, 2019; Kabul tarihi: April 26, 2019

Please cite this article as: Sivri Aydın D, Yayla M. Failure of getting intracranial translucency image in posterior fossa in the examination of singleton pregnancies at 11-13 weeks of gestation: reasons and outcomes. Perinatal Journal 2019;27(1):22-31. doi:10.2399/prn.19.0271004 


\section{Introduction}

Today, it is considered helpful to use ultrasonography examinations beginning from first trimester for the early diagnosis of fetal defects and malformations. ${ }^{[1,2)}$ Efforts are made and new methods are recommended for more than two decades for the early diagnosis of cranial malformations and other defects related with neural tube in particular. ${ }^{[1,3-5]}$ The most recent one is the measurement of intracranial translucency defined by Chaoi et al. in 2009, and the authors recommended the assessment between 11 and 13 weeks of gestation. ${ }^{[4]}$ While initial applications were mostly for the early diagnosis of spina bifida, ${ }^{[6-8]}$ further studies reported that this measurement could be used for chromosomal anomalies and other defects. ${ }^{[9-13]}$

The common point of origin of all these studies is the deviations from normal posterior brains structures examined between 11 and 13 weeks of gestation, and they aim to establish early diagnosis of both spina bifida and other neural tube defects. On the other hand, being unable to see or measure IT in the posterior fossa examination between 11 and 13 weeks of gestation does not always indicate an anomaly. ${ }^{[0]}$

We carried out some preliminary studies on IT presence in the previous years and generated some nomograms by the weeks of gestation. ${ }^{[1+16]}$ In our present study, we aimed to investigate the reasons and outcomes of being unable to see intracranial translucency (IT), and to determine the sensitivity, specificity, positive and negative predictive values and our diagnostic accuracy rate for the poor outcomes that may follow IT negativity by extending our current series slightly further.

\section{Methods}

The data of this study were obtained by the retrospective evaluation of the reports of 2670 singleton pregnancies examined between 11 and 13 weeks of gestation during a 7-year period between July 1st, 2011 and June 30th, 2018. Of the pregnancies, $94.3 \%$ were routine cases while $5.7 \%$ were referred cases, and $98.8 \%$ of the examinations were carried out transabdominally while $1.2 \%$ of them were carried out transvaginally. The cases whose crown-rump length (CRL) measurements were between 45 and $84 \mathrm{~mm}$ and which underwent detailed anatomic examination were included in the study group, and maternal age, anatomic-pathological characteristics of uterine, image quality, week of gestation, biometric data such as CRL, biparietal diameter (BPD), head circumference (HC), abdominal circumference (AC) and femur length (FL), nuchal translucency (NT) from genetic markers, nasal bone, the presence of ductus venosus diastolic flow, and also the presence of major malformation, if any, were noted for each case. NT and other genetic marker measurements were carried out in accordance with the guidelines of the Fetal Medicine Foundation (London, UK). ${ }^{[17]}$

The examination of cerebral structures and posterior fossa was carried out on classic NT examination plane as described by Chaoui et al., ${ }^{[4]}$ and the distance between the external echogenic line of inferior border of brain stem and the internal echogenic line of choroid plexus of the fourth ventricle was measured twice for IT measurement, and the mean value of these two measurements was calculated. In cases where sagittal plane view of IT was suspected, it was confirmed by transverse plane examination. The cases whose IT could not be seen or measured were not accepted pathologically for clinical follow-ups, the clinical follow-up protocol was not changed, and karyotyping procedures were carried out only according to the classical screening findings.

Second trimester examination was performed in all singleton pregnant women $(\mathrm{n}=1914)$ who did not found to have any pathology in the first trimester examination, whose pregnancies were not terminated and admitted for the follow-up, and the progress and results (defects and malformations, karyotype and microarray anomalies, fetal losses and terminations) of the cases whose IT could not be seen in particular were investigated. The cases whose IT could not be seen were noted if they had malformations in central nervous system (CNS) and other organs or were normal. Karyotype, extracellular (free) DNA, third trimester ultrasonography or delivery reports of the followed-up cases, if any, were accessed and their gestational prognoses were found. A total of 752 cases who did not show up to their follow-ups and whose prognosis could not be reached were excluded from the study. Second trimester ultrasonography examination was carried out in accordance with the guidelines of International Society of Ultrasound in Obstetrics \& Gynecology Education Committee (ISUOG) published in 2007. ${ }^{[18]}$

Sonography examinations for both trimesters were carried out by a perinatologist via GE-patented Voluson 730 Expert E8 and E10 devices (GE Healthcare, 
Table 1. The distribution of the cases according to their referral and follow-up status before and after intracranial translucency (IT) examination at 11-13 weeks of gestation.

\begin{tabular}{lccccc} 
& Total & Routine cases & Referred cases & Non-followed-up cases & Followed-up cases \\
\hline Total $n(\%)$ & $2666(100 \%)$ & $2548(95.57 \%)$ & $118(4.42 \%)$ & $752(28.21 \%)$ & $1914(71.79 \%)$ \\
IT $(+)$ n (\%) & $2558(95.95 \%)$ & $2456(96.39 \%)$ & $102(86.44 \%)$ & $740(98.40 \%)$ & $1818(94.98 \%)$ \\
IT(-) $n(\%)$ & $108(4.05 \%)$ & $92(3.61 \%)$ & $16(13.56 \%)$ & $12(1.60 \%)$ & $96(5.02 \%)$ \\
\hline Statistical significance & & \multicolumn{2}{c}{$\mathrm{p}<0.001$} & & $\mathrm{p}<0.05$ \\
\hline
\end{tabular}

Chicago, IL, USA) with the help of linear or 4-D probes (RAB 2-5, AB 2-7, RM6C, RIC 5-9, IC5-9, C1-5D).

SPSS 15.0 for Windows (SPSS Inc., Chicago, IL, USA) was used for statistical analysis. The definitive statistics were given as mean and standard deviation for numerical variables and as number and percentage for categorical variables. Normal distribution analysis was performed by Kolmogorov-Smirnov test, and Student's t-test was used to compare group mean values and chi-square test was used to obtain the rates of categorical variables among the groups. $\mathrm{p}<0.05$ was considered statistically significant. OR, sensitivity, specificity, positive and negative predictive values and diagnostic accuracy rate were used to evaluate the risk level of not getting IT image between the groups.

\section{Results}

In a total of 2670 singleton pregnancies which underwent first trimester examination, 752 cases were not followed up, 1832 cases were normal, 56 cases had classical karyotype or chromosomal microarray anomaly, 22 cases had fetus loss without chromosomal anomaly, and 4 cases had acrania. The cases with acrania were excluded from the study.

The rate of the cases whose IT could be measured in posterior fossa was $95.95 \%$ while the rate of those whose IT could not be measured was $4.05 \%(108 / 2666)$. IT measurement was not performed in $3.61 \%$ of the rou- tine examination group and in $13.56 \%$ of the referred case group. This 3.7 times higher difference between the groups was considered statistically significant $(\mathrm{p}<0.001)$. Of the entire group, $28.21 \%$ did not undergo a second examination, and this "non-followed-up" group was excluded from the study. Among the cases who came for a second examination, the rate of IT(-) cases was 3 times higher than those who did not come for the second examination, and this difference was statistically significant $(\mathrm{p}<0.05)$. The distribution of followed-up and nonfollowed-up cases according to whether they were referred cases or not is given in Table $\mathbf{1}$.

Weeks of gestation and mean CRL values of IT(+) and (-) groups were similar. However, mean NT values were significantly higher in IT(-) group $(\mathrm{p}<0.001)$ (Table 2).

The findings showing the relationship between IT measurability and prognosis are shown in Table 3. The rate of poor gestational prognosis in IT(-) group was higher than IT(+) group which was statistically significant (about 7 times higher: $3.14 \%$ vs. $21.87 \%$; $\mathrm{p}<0.001)$.

When the demographic and biometric characteristics of the cases whose IT could be measured were compared between the groups with normal and abnormal prognosis, it was found that maternal age and mean CRL, NT, IT, BPD and HC values were higher which were statistically significant although examina-

Table 2. Intracranial translucency (IT) at 11-13 weeks of gestation: biometric data of the followed-up cases

\begin{tabular}{lccccc} 
& $\mathbf{n}(\%)$ & Week of gestation & CRL (mm) & NT (mm) & IT (mm) \\
Total & $1914(100 \%)$ & $12.28 \pm 0.73$ & $62.08 \pm 6.88$ & $1.83 \pm 0.81$ & $1.82 \pm 0.29$ \\
IT(+) & $1818(94.98 \%)$ & $12.28 \pm 0.53$ & $62.16 \pm 6.76$ & $1.78 \pm 0.68$ & $(-)$ \\
IT(-) & $96(5.02 \%)$ & $12.25 \pm 0.60$ & $60.46 \pm 8.49$ & $2.63 \pm 2.09$ & $p<0.001$ \\
\hline Statistical significance & & $p>0.05$ & $p>0.05$ & - & - \\
\hline
\end{tabular}

CRL: crown-lump length; NT: nuchal translucency. 
tion week was similar (Table 4). Among them, the slightest difference was the mean IT measurement value. This finding indicated that measurable IT values in both groups showed initiative.

Chromosomal anomalies, fetal loss or termination of pregnancy were higher in the group with non-measured IT than the group with measured IT $(\mathrm{p}<0.001)$. No negative finding was found in $73.96 \%$ (71/96) of the group which was IT(-) and followed up, and cerebral findings (Blake's pouch cyst, mild ventriculomegaly, etc.) which require follow-up but do not affect the prognosis were observed in $4.17 \%$ (4/96) of them. The IT negativity in the initial findings of 71 cases, which were considered normal, was interpreted as false negativity. In this case, the impact of actual IT negativity $(\mathrm{n}=25)$ on poor prognosis was calculated $84 \%$ (Table 5).

When ultrasonography examinations of IT(-) cases were assessed as sub-groups, the rates of chromosomopathy markers of early period (NT, nasal bone, ductus venosus), and CNS and non-CNS malformations and defects were found higher than the IT(+) group $(\mathrm{p}<0.001)$. The markers and malformations which can be seen after 13 weeks of gestation were similar in both groups. Karyotype and cfDNA analyses were also referred much more in IT(-) group and more chromosomopathies were found in this group $(\mathrm{p}<0.001)$ (Table 6).
Table 3. The distribution of the cases with normal and abnormal prognosis after intracranial translucency (IT) examination at 11-13 weeks of gestation.

\begin{tabular}{lccc} 
& $\begin{array}{c}\text { Followed-up } \\
\text { cases }\end{array}$ & $\begin{array}{c}\text { Normal } \\
\text { prognosis* }\end{array}$ & $\begin{array}{c}\text { Abnormal } \\
\text { prognosis }\end{array}$ \\
\hline Total $\mathrm{n}(\%)$ & $1914(100 \%)$ & $1836(95.92 \%)$ & $78(4.08 \%)$ \\
IT $(+) \mathrm{n}(\%)$ & $1818(94.98 \%)$ & $1761(96.86 \%)$ & $57(3.14 \%)$ \\
IT(-) $\mathrm{n}(\%)$ & $96(5.02 \%)$ & $75(78.13 \%)$ & $21(21.87 \%)$ \\
\hline Chi-square tes & & \multicolumn{2}{c}{$\mathrm{p}<0.001$} \\
\hline
\end{tabular}

*Those with normal findings in second trimester perinatal ultrasonography, cfDNA, karyotype or delivery. ${ }^{\dagger}$ Those with abortion, fetal loss or anomaly, karyotype or chromosome pathology.

Of the IT non-measurability, the sensitivity was $26.9 \%$, the specificity was $95.9 \%$, the positive prediction value was $21.9 \%$, the negative prediction value was $96.9 \%$, the accuracy rate was $93 \%$, the odds ratio was 8.7 and the confidence interval was $5.0-15.0$ to predict the poor gestational prognosis. Diagnostic performance results related with various system anomalies, chromosomal anomalies, abortions and gestational losses which establish the poor prognosis are shown in Table 7.

When technical and imaging conditions during the examination are taken into consideration in all cases of the main group, the maternal age, reported obesity, uterine anomalies, myomas and position disorders, and posture disorders of fetus were statistically different in

Table 4. The comparison demographic and biometric data of intracranial translucency (IT)-measured cases ( $n=1818$ ) between the groups with normal and abnormal prognoses.

\begin{tabular}{lcccccccc} 
& N (\%) & Age & Week of gestation & CRL & NT & IT & BPD & HC \\
Normal prognosis & $1761(96.86 \%)$ & $31.74 \pm 3.89$ & $12.28 \pm 0.52$ & $62.26 \pm 6.71$ & $1.72 \pm 0.47$ & $1.82 \pm 0.29$ & $20.37 \pm .21$ & $77.15 \pm 7.75$ \\
Abnormal prognosis & $57(3.14 \%)$ & $34.39 \pm .77$ & $12.2 \pm 0.70$ & $58.67 \pm 8.23$ & $3.79 \pm 2.13$ & $1.94 \pm 0.45$ & $19.57 \pm 2.80$ & $74.02 \pm 9.75$ \\
\hline Statistical significance & & $\mathrm{p}<0.001$ & $\mathrm{p}>0.05$ & $\mathrm{p}<0.001$ & $\mathrm{p}<0.001$ & $\mathrm{p}<0.05$ & $\mathrm{p}<0.05$ & $\mathrm{p}<0.05$ \\
\hline
\end{tabular}

BPD: biparietal diameter; CRL: crown-lump length; HC: head circumference; NT: nuchal translucency.

Table 5. The distribution of prognosis according to the sub-groups after intracranial translucency (IT) examination at 11-13 weeks of gestation.

\begin{tabular}{lccccc} 
& $\mathbf{n ( \% )}$ & Chromosomal anomaly & Abortion or losses* & Temporary finding $^{\dagger}$ & Normal $^{\ddagger}$ \\
Total & $1914(100 \%)$ & $56(2.93 \%)$ & $22(1.15 \%)$ & $64(3.34 \%)$ & $1772(92.58 \%)$ \\
IT(+) & $1818(94.98 \%)$ & $44(2.42 \%)$ & $13(0.72 \%)$ & $60(3.30 \%)$ & $1701(93.56 \%)$ \\
IT(-) & $96(5.02 \%)$ & $12(12.5 \%)$ & $9(9.38 \%)$ & $4(4.17 \%)$ & $71(73.96 \%)$ \\
\hline Chi-square test & & $p<0.001$ & $p<0.001$ & $p>0.05$ & $p<0.001$ \\
\hline
\end{tabular}

*Abortions or intrauterine fetal losses with unknown or normal karyotype. ${ }^{\top}$ Temporary finding: The cases which exhibit changes within physiological borders in the cere-

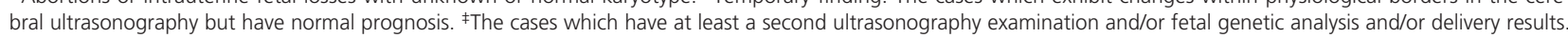


Table 6. Intracranial translucency (IT) examination at 11-13 weeks of gestation and the findings of malformation and karyotype obtained afterwards.

\begin{tabular}{|c|c|c|c|c|c|c|c|c|}
\hline & n (\%) & 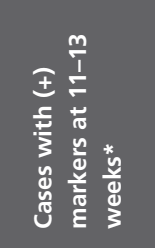 & 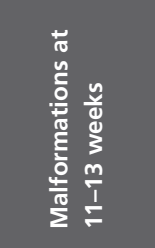 & 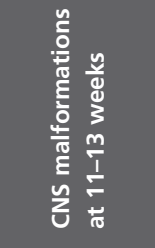 & 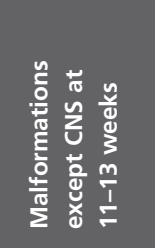 & 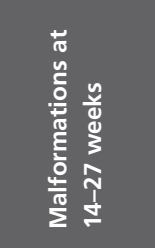 & 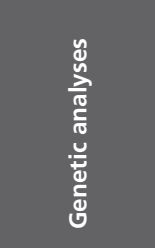 & 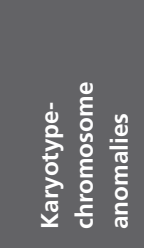 \\
\hline Total n (\%) & $1914(100 \%)$ & $51(2.66 \%)$ & $38(1.98 \%)$ & $24(1.25 \%)$ & $27(1.41 \%)$ & $22(1.15 \%)$ & $169(8.83 \%)$ & $56(2.93 \%)$ \\
\hline $\mathrm{IT}(+) \mathrm{n}(\%)$ & $1818(94.98 \%)$ & $29(1.59 \%)$ & $21(1.15 \%)$ & $14(0.77 \%)$ & $13(0.71 \%)$ & $21+(1.18 \%)$ & $140(7.70 \%)$ & $44(2.42 \%)$ \\
\hline IT(-) n (\%) & $96(5.02 \%)$ & $22(22.92 \%)$ & $17(17.71 \%)$ & $10(10.42 \%)$ & $14(14.58 \%)$ & $1^{\dagger}(1.39 \%)$ & $29(30.21 \%)$ & $12(12.50 \%)$ \\
\hline Statistical significance & & $p<0.001$ & $p<0.001$ & $p<0.001$ & $p<0.001$ & $p>0.05$ & $p<0.001$ & $p<0.001$ \\
\hline
\end{tabular}

*Early genetic markers: nuchal translucency, nasal bone and ductus venosus abnormalities. ${ }^{\dagger}$ The data calculated on the basis of second trimester examination finding.

IT(-) cases than IT(+) cases. The details can be seen in Table 8. It was found that these factors are prominent and there is no fetal pathological results in the cases $(\mathrm{n}=71)$ which are false negative in particular. When these cases causing false negativity are excluded, the rates of chromosomal anomaly, malformation and negative prognosis increase to $48 \%, 68 \%$ and $84 \%$, respectively. Some cases with normal and abnormal findings are shown in Figs. 1-4.

\section{Discussion}

Most of the studies conducted on the intracranial translucency are for the early diagnosis of open spina bifida. $^{[6-8]}$ In our study, we aimed to investigate the reasons for non-measurability of IT and what outcomes are introduced in the presence of other findings following this finding.

We found in our study that IT measurement was not done in approximately $4 \%$ of all cases during early period examination. This rate was between $0 \%$ and $5 \%$ in other series. ${ }^{[4,19-21]}$ When we reviewed the literature, we found out that many studies on IT issue were rather archive studies which investigated recorded images retrospectively. ${ }^{[13,22,23]}$ When these examinations were reevaluated, it was found that any fluid image seen in posterior fossa of some fetuses could be measured as IT by accident. ${ }^{[8]}$ We did not scrutinize false positivity as it may be difficult to carry out prospective investigation on archived images in the studies with wide series such as ours; however, we decreased the negative influence of this matter on our results by investigating the follow-ups and prognoses of IT(+) cases.

Considering the followed-up cases $(n=96)$ in our series, we found that $73.9 \%$ of IT(-) cases were completely normal, $4.2 \%$ of them had normal prognoses together with mild findings such as Blake's pouch cyst, and $21.87 \%$ of them had significant issues. When we excluded the cases that we interpreted as false negative, the rate of actual IT(-) cases was $1.3 \%$ (25/1914). We revised the rate of ending with a poor prognosis as $84 \%$.

In our study series, the number of IT(-) cases among the pregnant women referred with other rea-

Table 7. Sensitivity, specificity, positive and negative predictivity, accuracy rates and odds ratio of intracranial translucency (IT) negativity to predict various anomalies, fetal losses and final poor prognosis.

\begin{tabular}{lccccccc} 
& Sensitivity & Specificity & PPV & NPV & Accuracy & OR & $95 \%$ Cl \\
\hline 11-13 week anomaly & $44.7 \%$ & $95.8 \%$ & $17.7 \%$ & $98.8 \%$ & $94.8 \%$ & 18.4 & $9.3-36.3$ \\
Non-CNS anomalies & $51.9 \%$ & $95.7 \%$ & $14.9 \%$ & $93.9 \%$ & $95.0 \%$ & 23.7 & $10.8-52.0$ \\
CNS anomalies & $41.7 \%$ & $95.4 \%$ & $10.4 \%$ & $99.2 \%$ & $94.8 \%$ & 15 & $6.5-34.7$ \\
Chromosomal anomalies & $21.4 \%$ & $95.5 \%$ & $12.5 \%$ & $97.6 \%$ & $93.3 \%$ & 5.8 & $2.9-11.3$ \\
Abortion - loss & $29.2 \%$ & $95.9 \%$ & $21.8 \%$ & $97.2 \%$ & $93.4 \%$ & 9.7 & $5.6-17.0$ \\
Poor prognosis & $26.9 \%$ & $95.9 \%$ & $21.9 \%$ & $96.9 \%$ & $93.1 \%$ & 8.7 & $5.0-15.0$ \\
\hline
\end{tabular}

Cl: confidence interval; NPV: negative predictive value; OR: odds ratio; PPV: positive predictive value. 
Table 8. Intracranial translucency (IT) finding at 11-13 weeks of gestation and the relationship between technical and maternal characteristics.

\begin{tabular}{lccccc} 
& $\mathbf{n}$ & Maternal age & Technical difficulty* & Uterine reasons & Total $^{\dagger}$ \\
Total & 2666 & $31.57 \pm 4.00$ & $31(1.16 \%)$ & $151(5.66 \%)$ & $182(6.82 \%)$ \\
IT(+) & 2558 & $31.86 \pm 3.97$ & $12(0.47 \%)$ & $121(4.73 \%)$ & $133(5.20 \%)$ \\
IT(-) & 108 & $33.16 \pm 4.09$ & $19(17.59 \%)$ & $30(27.78 \%)$ & $49(45.37 \%)$ \\
\hline Statistical significance & - & $p<0.01$ & $p<0.001$ & $p<0.001$ & $p<0.001$ \\
\hline
\end{tabular}

*Difficulty in imaging, inconvenient fetal position. +Uterine anomaly, retroversion, myoma.

sons not related with IT was higher in a statistically significant manner. Also, the rate of being not followed up of IT(-) cases was lower than IT(+) cases $(\mathrm{p}<0.05)$. Although the families in this group were not recommended any procedure or examination which may affect prognosis as IT could not be seen, the presence of other reasons required a second examination or an invasive procedure. We interpreted our two findings as an indicator that IT negativity might accompany other pathologies.

When we compared fetal clinical findings and biometric parameters in IT(-) and IT(+) groups, we observed that mean weeks of gestation and CRL measurements were similar but mean NT was higher in IT(-) group. Similarly, maternal age was also higher in this group. When we interpreted our findings together with further examinations, we determined that this was caused by chromosomal anomalies in particular. Martinez-Ten et al. ${ }^{[23]}$ reported in their study that there was an increase in NT in 50\% of IT(-) cases and 71\% of the entire group had major chromosomal anomalies. When we excluded false negative cases, the rate of major chromosomal anomaly was $48 \%$.

On the other hand, when we excluded IT(-) cases and took only IT(+) cases into consideration, we found that the mean values of IT, NT and other biometric parameters deviated in a statistically significant manner among the case groups with normal and abnormal prognoses. While maternal age, NT and IT had higher values at similar weeks of gestation, CRL, BPD and $\mathrm{HC}$ values were lower. The reason for these findings was the presence of chromosomal anomalies in the same group and we interpreted that posterior fossa expansion accompanied other typical findings of chro-
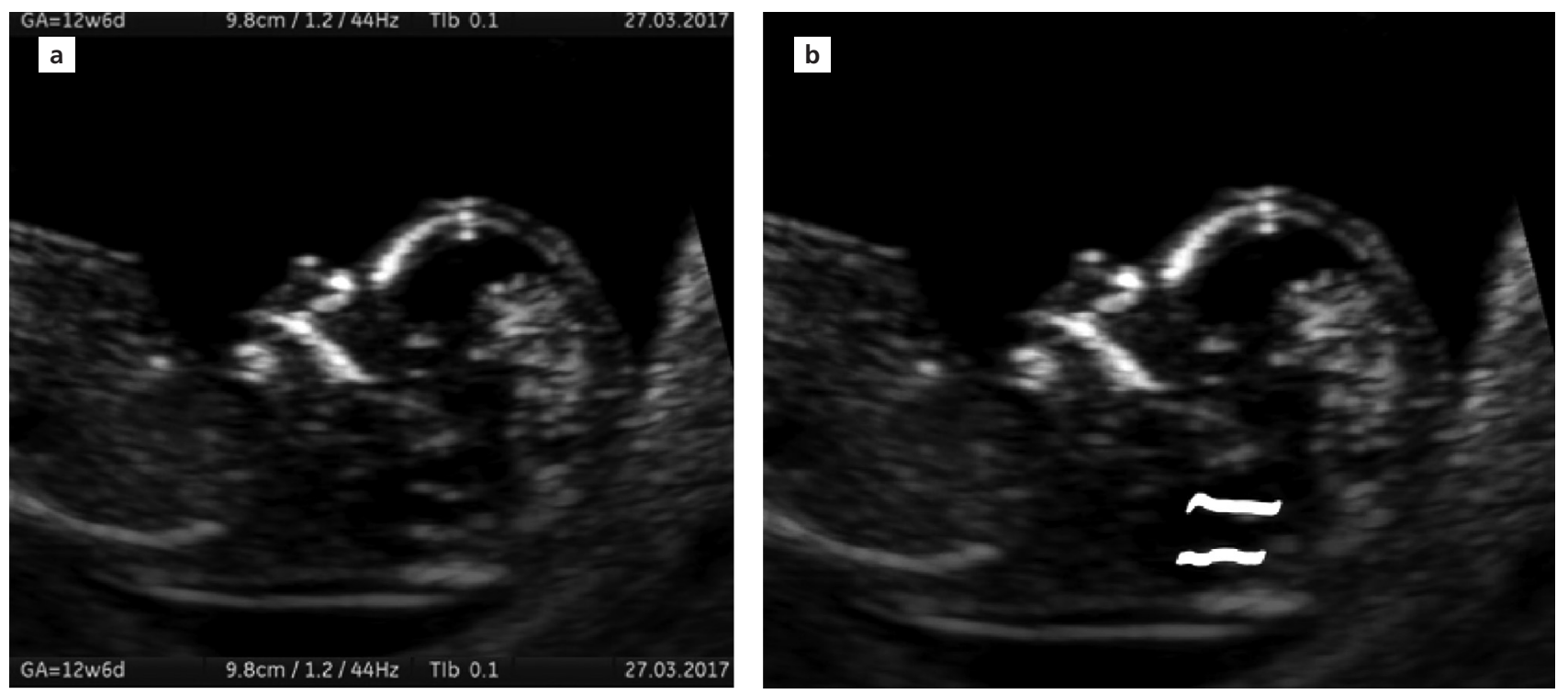

Fig. 1. (a) Normal intracranial translucency (IT) image and (b) drawing in posterior fossa imaging. 


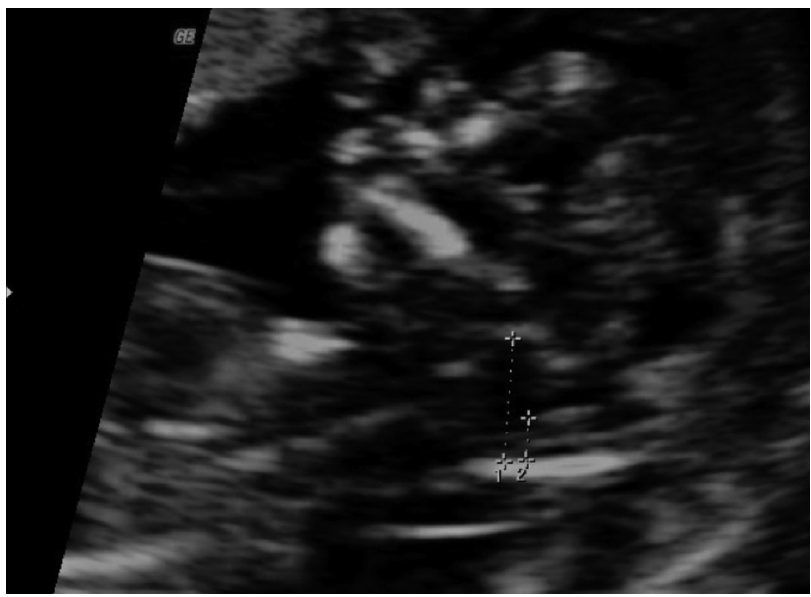

Fig. 2. Abnormal intracranial translucency (IT) image in posterior fossa: increased distance between brain stem and occipital bone.

mosomopathy. Volpe et al ${ }^{[13]}$ highlighted in their study that the reason of fluid increase seen in IT-like areas in the posterior fossa could be the presence of various minor and major chromosomal anomalies.

When we investigated the cases, whose IT could not been in the posterior fossa examination during the first trimester, at that and further weeks of gestation, we noticed that the rates of chromosomal anomalies, fetal defects, fetal losses and termination of pregnancy were higher. For example, CNS defects increased 15 times, abortion and fetal losses increased 10 times, and chromosomal anomalies increased 6 times. The frequency of occurrence for any of them increases approximately 9 times. In fact, Ferreira et al., ${ }^{[10]}$ Bornstein et al., ${ }^{[12]}$ Volpe et al., ${ }^{[13]}$ Fong et al., ${ }^{[20]}$ Martinez-Ten et al., ${ }^{[23]}$ and Volpe et al. ${ }^{[24]}$ showed that posterior fossa examinations may help to diagnose chromosomopathy and CNS defects.

The most significant and prominent finding in our study was the significant increase $(8.7$ times) in the rates of poor prognostic criteria such as chromosomopathy, fetal defect and pregnancy loss mentioned above when other findings accompanying the failure of seeing or measuring IT are present. Volpe et al. ${ }^{[13]}$ expressed that the pregnancy was terminated in $71 \%$ $(12 / 17)$ of the cases who had abnormal image in the posterior fossa. In the study of Martinez-Ten et al., ${ }^{[23]}$ the rate of ended or terminated case was $82 \%(23 / 28)$ after similar findings. In our series, the rate of ended-

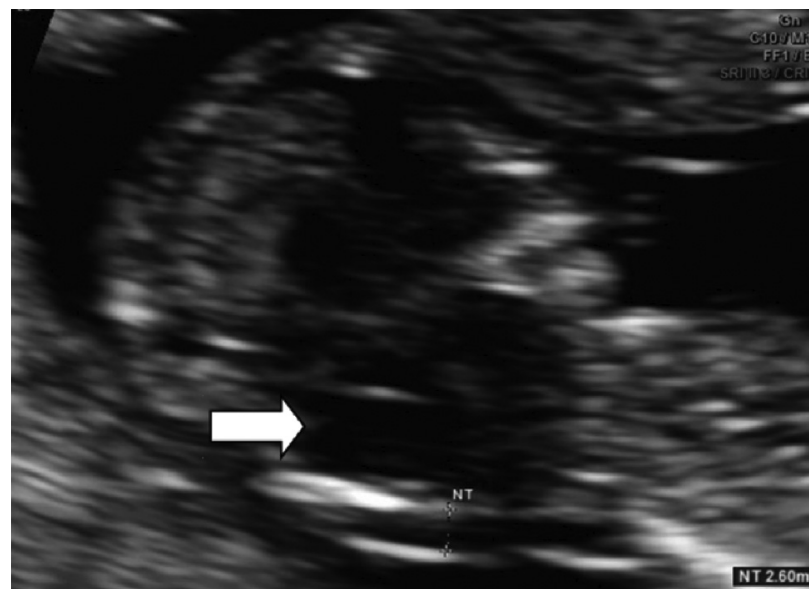

Fig. 3. Dandy-Walker malformation at 12 weeks of gestation: posterior fossa is wide (arrow), and there is no typical intracranial translucency (IT) image.

terminated cases we found after actual negatives were determined was $84 \%(21 / 25)$, and it was similar to other studies.

Volpe et al. ${ }^{[24]}$ described 3 pathognomonic markers which also included posterior fossa abnormalities in the brain, and they highlighted that cerebral or chromosomal anomalies increased in the presence of any of them and that they affected gestational prognosis negatively. The same authors reported in another study ${ }^{[13]}$ that 9 of 17 cases, who had abnormal images in the posterior fossa, had chromosomal anomalies, 7 of them had cranial malformation, 5 of them had extracranial

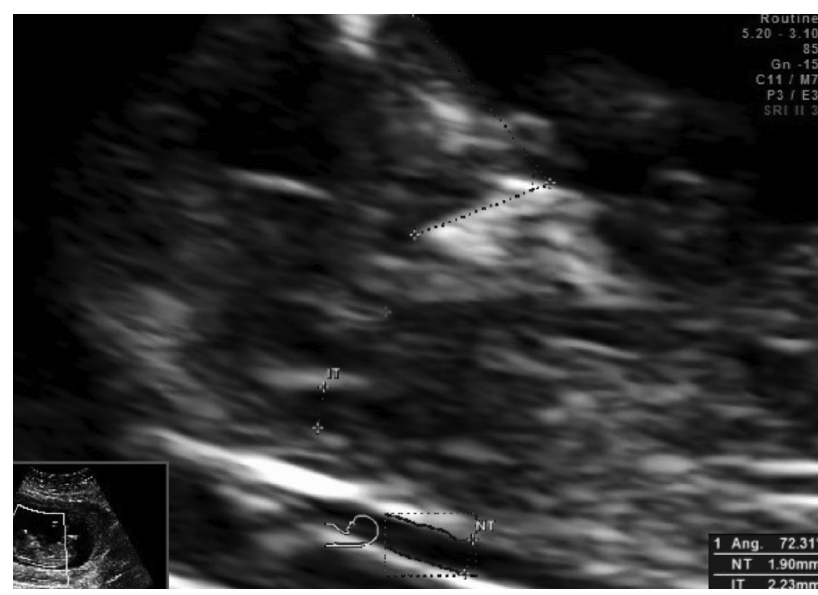

Fig. 4. Intracranial translucency (IT) view in posterior fossa at 13 weeks of gestation at holoprosencephaly: 4th ventricle choroid plexus is closer to the occipital bone than expected. 
malformation, and only 5 cases had good prognosis. Martinez-Ten et al. ${ }^{[23]}$ studied 28 cases whose choroid plexus of 4th ventricle could not be seen, and found karyotype anomaly in 20 of them, and systemic malformation in a total of 19 cases in which 12 of them were CNS anomaly, and only 5 cases had normal prognosis.

Some studies highlighted that the examination of IT during the early periods of pregnancy could be effective to detect chromosomopathies, malformations and poor gestational prognosis, and that it may indicate cerebral malformations such as Dandy-Walker and Blake's pouch cyst persistence which may develop at late period. ${ }^{[11-13,23]}$ The findings of the early period in our study are also similar. We did not obtain a significant result when we distributed other 22 malformations, which we found at and after 14 weeks of gestation, by the groups.

Although the examination of IT and therefore posterior fossa during this period does not completely supersede NT and other genetic markers used for the early diagnosis of trisomy 21 , it is powerful enough to help for suspecting trisomies and other karyotype anomalies in some cases. ${ }^{[9,10]}$ In fact, some studies ${ }^{[1,25]}$ showed that posterior fossa abnormalities were apparent not in trisomy 21 cases but in triploidy and trisomy 13 and 18 cases. In our study, we did not investigate chromosomal anomalies by establishing sub-groups, but we found that IT image and measurements in chromosomopathies differed from the cases in the normal group. We detected more chromosome markers in the ultrasonography examinations of IT(-) cases than IT(+) cases, and we found more procedures performed for genetic evaluation and a higher rate of abnormal karyotype results obtained. However, we did not find any difference between the groups in terms of markers and malformations which can be seen after 14 weeks of gestation.

The first point of origin for IT measurement was for the early diagnosis of open spina bifida and there were different study results. ${ }^{[4,6-8,15]}$ The further investigations showed that IT screening could help not only spina bifida but also other anomalies. ${ }^{[9-13]}$ In our series, we found IT negativity in 2 spina bifida cases as well as $8 \mathrm{CNS}$ cases, and the early detection of CNS anomalies by IT screening had a sensitivity of $42 \%$ with a $95 \%$ accuracy rate. In other series, this rate varied between $0 \%$ and $100 \% .^{[4,6-8,15]}$
While the positive relationship between poor prognosis and the failure of seeing IT was apparent in our study, the impact of the measurement IT distance range on the prognosis exhibited only a statistically poor relationship. In other words, IT values of the cases with poor prognosis may conflict with normal values. Therefore, being able to measure IT is not a strong parameter to predict prognosis, but the view of IT and its relationship with its vicinity are more important.

On the other hand, posterior fossa may have a cystic appearance between 15 and 18 weeks of gestation in $10 \%$ of normal fetuses. They can later be interpreted as 4th ventricle or Blake's pouch cyst. ${ }^{[2]}$ The presence of similar image also during earlier weeks of gestation is also an expected finding. Therefore, establishing posterior fossa cyst diagnosis during very early periods can be qualified as a malpractice. In our study, we found posterior fossa cyst in 45 cases, and $24 \%$ of them resulted in poor prognosis. None of the cases with isolated findings underwent an invasive procedure that would change routine follow-up, and only second examination time was moved to an earlier time.

Volpe et al. ${ }^{[13]}$ stated that posterior fossa examination can be a guiding parameter for malformations in this region and chromosomal anomalies. In our study, the sensitivity of IT negativity for chromosomal anomalies was $21 \%$, and the odds ratio was 5.8 . The findings of our study were guiding parameters for CNS and systemic malformations rather than chromosomal anomalies.

Lafouge et al. ${ }^{[1]]}$ reported that Blake's pouch could be seen by sonographic images similar to the lack of IT, but differential diagnosis could be established by the examinations during following weeks and prognosis was good. Martinez-Ten et al. ${ }^{[23]}$ found the rate of Blake's pouch persistence in $7.1 \%(2 / 28)$ in their series similar to our study. In our study, the rate to detect Blake's pouch was $16 \%(4 / 25)$ in our actual IT(-) cases.

Also, we did not find IT negativity in any of the cases with conditions which may be temporary and do not affect prognosis negatively such as mild ventriculomegaly. Some studies reported that the distance with brain stem and occipital bone can be more helpful in the early diagnosis of open spina bifida and DandyWalker malformation. ${ }^{[13,26-28]}$ While this distance becomes narrow in spina bifida, it increases in DandyWalker malformation. 
When we considered all examined studies, we observed that the rates of maternal age, obesity, uterine anomalies, myoma and position disorders, and fetal posture disorders were higher in IT(-) cases than IT(+) cases. We noticed that these factors are prominent and there is no fetal pathological results in the cases $(n=71)$ which are false negative in particular. Papastefanou et al. ${ }^{[9]}$ and Fong et al. ${ }^{[20]}$ also reported similar results.

The research of intracranial translucency has been in our agenda over the last decade, and it has become one of the cornerstones for better assessment of fetal anatomy. The results that we obtained in our study in which we aimed to investigate the rates, reasons and results for being unable to see or measure this image during perinatal examination are:

- Intracranial translucency can be seen and measured during routine perinatal examination with a rate of $96 \%$, and this rate is almost $99 \%$ when we exclude false negative cases,

- Uterine anomalies, myomas, and the changes in fetal posture may cause technical difficulties and false negative findings,

- The cases whose IT cannot be seen are, independent from this finding, are examined much more during further weeks of gestation and they expose to more genetic researches,

- The negative variances in fetal biometric parameters, NT and similar genetic markers, CNS and non-CNS anomalies, genetic disorders, fetal losses and abortions have higher rates in IT(-) cases.

- When the cases which are false negative for IT are ruled out, the prognosis rate is $84 \%$.

Not assessing false positivity, not repeating the measurements by a second specialist and performing postmortem examination in few cases are the weak points of our study.

\section{Conclusion}

The findings of our study make us think that the examination and measurement of intracranial translucency can be used as a parameter helping classical methods for the early diagnosis of CNS or systemic malformations and some chromosomal anomalies, and that it can be a part of perinatal assessment.

Conflicts of Interest: No conflicts declared.

\section{References}

1. Syngelaki A, Chelemen T, Dagklis T, Allan L, Nicolaides KH. Challenges in the diagnosis of fetal non-chromosomal abnormalities at 11-13 weeks. Prenat Diagn 2011;31:90-102.

2. Vayna AM, Veduta A, Duta S, Panaitescu AM, Stoica S, Buinoiu N, et al. Diagnosis of fetal structural anomalies at 11 to 14 weeks. J Ultrasound Med 2018;37:2063-73.

3. Sebire NJ, Noble PL, Thorpe-Beeston JG, Snijders RJM, Nicolaides KH. Presence of the 'lemon' sign in fetuses with spina bifida at the 10-14-week scan. Ultrasound Obstet Gynecol 1997;10:403-5.

4. Chaoui R, Benoit B, Mitkowska-Wozniak H, Heling KS, Nicolaides KH. Assessment of intracranial translucency (IT) in the detection of spina bifida at the 11-13-week scan. Ultrasound Obstet Gynecol 2009;34:249-5.

5. Timor-Tritsch IE, Monteagudo A. Transvaginal sonographic evaluation of the fetal central nervous system. Obstet Gynecol Clin North Am 1991;18:713-48.

6. Kavalakis I, Souka AP, Pilalis A, Papastefanou I, Kassanos D. Assessment of the posterior brain at 11-14 weeks for the prediction of open neural tube defects. Prenat Diagn 2012;32: 1143-6.

7. Mangione R, Dhombres F, Lelong N, Amat S, Atoub F, Friszer S, et al. Screening for fetal spina bifida at the 11-13week scan using three anatomical features of the posterior brain. Ultrasound Obstet Gynecol 2013;42:416-20.

8. Chaoui R, Benoit B, Heling KS, Kagan KO, Pietzsch V, Sarut Lopez A, et al. Prospective detection of open spina bifida at 11-13 weeks by assessing intracranial translucency and posterior brain. Ultrasound Obstet Gynecol 2011;38:722-6.

9. Papastefanou I, Souka AP, Pilalis A, Panagopoulos P, Kassanos D. Fetal intracranial translucency and cisterna magna at 11 to 14 weeks: reference ranges and correlation with chromosomal abnormalities. Prenat Diagn 2011;31:1189-92.

10. Ferreira AF, Syngelaki A, Smolin A, Vayna AM, Nicolaides $\mathrm{KH}$. Posterior brain in fetuses with trisomy 18 , trisomy 13 and triploidy at 11 to 13 weeks' gestation. Prenat Diagn 2012;32: 854-8.

11. Lafouge A, Gorincour G, Desbriere R, Quarello E. Prenatal diagnosis of Blake's pouch cyst following first-trimester observation of enlarged intracranial translucency. Ultrasound Obstet Gynecol 2012;40:479-80.

12. Bornstein E, Goncalves Rodríguez JL, Alvarez Pavon EC, Quiroga H, Or D, Divon MY. First-trimester sonographic findings associated with a Dandy-Walker malformation and inferior vermian hypoplasia. J Ultrasound Med 2013;32:18638.

13. Volpe P, Contro E, Fanelli T, Muto B, Pilu G, Gentile M. Appearance of the fetal posterior fossa at 11-14 weeks in fetuses with Dandy-Walker malformation or chromosomal anomalies. Ultrasound Obstet Gynecol 2016;47:720-5.

14. Ergin RN, Yayla M. The nomogram of intracranial translucency in the first trimester in singletons. J Turk Ger Gynecol Assoc 2012;1;13:153-6. 
15. Yuksel MA, Arisoy R, Erdogdu E, Imamoglu M, Yayla M, Sen C. Relationship between first trimester visualization of the intracranial translucency and spina bifida. Arch Gynecol Obstet 2015;291:513-8.

16. Sivri Aydın D, Yayla M. Evaluation of the fourth ventricle and nomogram of intracranial translucency at 11-13 weeks of gestation. Perinatal Journal 2018;26:102-5.

17. Nicolaides KH. First-trimester screening for chromosomal abnormalities. Semin Perinatol 2005;29:190-4.

18. International Society of Ultrasound in Obstetrics \& Gynecology Education Committee (ISUOG). Sonographic examination of the fetal central nervous system: guidelines for performing the 'basic examination' and the 'fetal neurosonogram'. Ultrasound Obstet Gynecol 2007;29:109-16.

19. Adiego B, Illescas T, Martinez-Ten P, Bermejo C, PerezPedregosa J, Wong AE, et al. Intracranial translucency at 11-13 weeks of gestation: prospective evaluation and reproducibility of measurements. Prenat Diagn 2012;32:25963 .

20. Fong KW, Dengler J, Toi A, Menezes RJ, Karimzad Y, Okun N. Prospective study of intracranial translucency and the posterior brain in normal fetuses at the 11 - to 13 -week scan. J Ultrasound Med 2014;33:1373-9.

21. Lane A, Lee L, Traves D, Lee A. Intracranial translucency assessment at first trimester nuchal translucency ultrasound. J Med Imaging Radiat Oncol 2017;61:185-9.
22. Contro E, Volpe P, De Musso F, Muto B, Ghi T, De Robertis $\mathrm{V}$, et al. Open fourth ventricle prior to 20 weeks' gestation: a benign finding? Ultrasound Obstet Gynecol 2014;43:154-8.

23. Martinez-Ten P, Illescas T, Adiego B, Estevez M, Bermejo C, Wong AE, et al. Non-visualization of choroid plexus of fourth ventricle as first-trimester predictor of posterior fossa anomalies and chromosomal defects. Ultrasound Obstet Gynecol 2018;51:199-207.

24. Volpe P, Muto B, Passamonti U, Rembouskos G, De Robertis V, Campobasso G, et al. Abnormal sonographic appearance of posterior brain at 11-14 weeks and fetal outcome. Prenat Diagn 2015;35:717-23.

25. Loureiro T, Ferreira AF, Ushakov F, Montenegro N, Nicolaides KH. Dilated fourth ventricle in fetuses with trisomy 18 , trisomy 13 and triploidy at 11-13 weeks' gestation. Fetal Diagn Ther 2012;32:186-9.

26. Lachmann R, Chaoui R, Moratalla J, Picciarelli G, Nicolaides $\mathrm{KH}$. Posterior brain in fetuses with open spina bifida at 11 to 13 weeks. Prenat Diagn 2011;31:103-6.

27. Lachmann R, Sinkovskaya E, Abuhamad A. Posterior brain in fetuses with Dandy-Walker malformation with complete agenesis of the cerebellar vermis at 11-13 weeks: a pilot study. Prenat Diagn 2012;32:765-9.

28. Garcia-Posada R, Eixarch E, Sanz M, Puerto B, Figueras F, Borrell A. Cisterna magna width at 11-13 weeks in the detection of posterior fossa anomalies. Ultrasound Obstet Gynecol $2013 ; 41: 515-20$

Bu makalenin kullanım izni Creative Commons Attribution-NoCommercial-NoDerivs 3.0 Unported (CC BY-NC-ND3.0) lisansı aracıllğılla bedelsiz sunulmaktadır. / This work is licensed under the Creative Commons Attribution-NonCommercial-NoDerivs 3.0 Unported (CC BY-NC-ND3.0) License. To view a copy of this license, visit http://creativecommons.org/licenses/by-nc-nd/3.0/ or send a letter to Creative Commons, PO Box 1866, Mountain View, CA 94042, USA. 